\title{
Interaction of proteins and amino acids with iso-a-acids during wort preparation in the brewhouse
}

\author{
Nele Gänz ${ }^{1,2} \mathbb{2} \cdot$ Tobias Becher $^{1} \cdot$ Stephan Drusch ${ }^{2} \cdot$ Jean Titze $^{3}$
}

Received: 3 July 2021 / Accepted: 20 November 2021 / Published online: 2 December 2021

(c) The Author(s) 2021

\begin{abstract}
This paper investigates the binding behavior of iso- $\alpha$-acids from hops on free wort amino acids and proteins concerning the wort production process in breweries. The studies were carried out with different amino acids, bovine serum albumin and wort. To identify the nature of reaction between iso- $\alpha$-acids and these substances, analyses of free amino nitrogen, HPLC and isothermal titration calorimetry were performed. According to the results, the iso- $\alpha$-acids do not form covalent bonds with free amino acids of wort. However, iso- $\alpha$-acids, especially isohumulone and isoadhumulone, form ionic bonds with wort proteins. A distinction must be made between proteins that are present in the hot trub, and those that are still dissolved in the hot wort. Proteins that are already coagulated and precipitated no longer react with iso- $\alpha$-acids. Future experiments will investigate whether the established ionic bonds between iso- $\alpha$-acids and proteins from the wort preparation process are maintained during fermentation until the finished beer or beer foam. If this is the case, which is induced by the experiments, there is a measurable loss of iso- $\alpha$-acids in the hot wort, but at the same time, a gain for the later beer foam retention, as the iso- $\alpha$-acids will stabilize it.
\end{abstract}

Keywords Iso- $\alpha$-acids $\cdot$ Amino acids $\cdot$ Proteins $\cdot$ Beer production $\cdot$ ITC $\cdot$ HPLC

\section{Introduction}

Four raw materials are needed for beer production: water, malt, hops and yeast. Hops give beer its typical bitter taste and hop aroma. The hop acids, hop oils and hop polyphenols originate from the lupulin glands of the female hop plant. During wort boiling in the brewhouse, the hop $\alpha$-acids undergo a transformation by contraction of the acyloin ring. The hop $\alpha$-acids isomerize to iso- $\alpha$-acids. In total, six possible types are formed: isohumulone, isoadhumulone and isocohumulone as well as their cis- and trans-epimers. The converted iso- $\alpha$-acids contribute significantly to the bitter

Nele Gänz

nelebastgen@gmail.com

1 Ziemann Holvrieka GmbH, Schwieberdinger Straße 86, 71636 Ludwigsburg, Germany

2 Technische Universität Berlin, Institute of Food Technology and Food Chemistry, Königin-Luise-Str. 22, 14195 Berlin, Germany

3 Anhalt University of Applied Sciences, Bernburger Str. 55, 06366 Köthen, Anhalt, Germany taste of beer, so they and the reaction pathway to them are of particular importance.

On one hand, the isomerization reaction is influenced by parameters such as extract and $\mathrm{pH}$ value of the wort, temperature, boiling time as well as hopping rate of hop $\alpha$-acids. On the other hand, there are losses of already isomerized $\alpha$-acids [1-4]. In the brewhouse, 25-30\% bitter substances are lost with the spent hops and $25-40 \%$ by adsorption on the hot trub [5]. According to Specht [6], the less acidic the milieu is the more bitter substances are molecularly dissolved; in an acidic environment, they are colloidally dissolved. In the wort, these colloidally dissolved bitter substances probably form adsorption compounds with certain unspecified proteins, resulting in losses due to hot trub formation. Howard and Slater [7] published that the losses of bitter compounds to the hot trub are primarily due to the adsorption of $\alpha$-acids to proteins and secondarily to the adsorption of iso-compounds to proteins. The data obtained by Brenner et al. [8] indicate that the bitter compounds that precipitate with the hot trub have changed chemically, as they do not dissolve back into wort.

Figure 1 shows a summary of possible interactions or bonds between iso- $\alpha$-acids and proteins or defined amino 


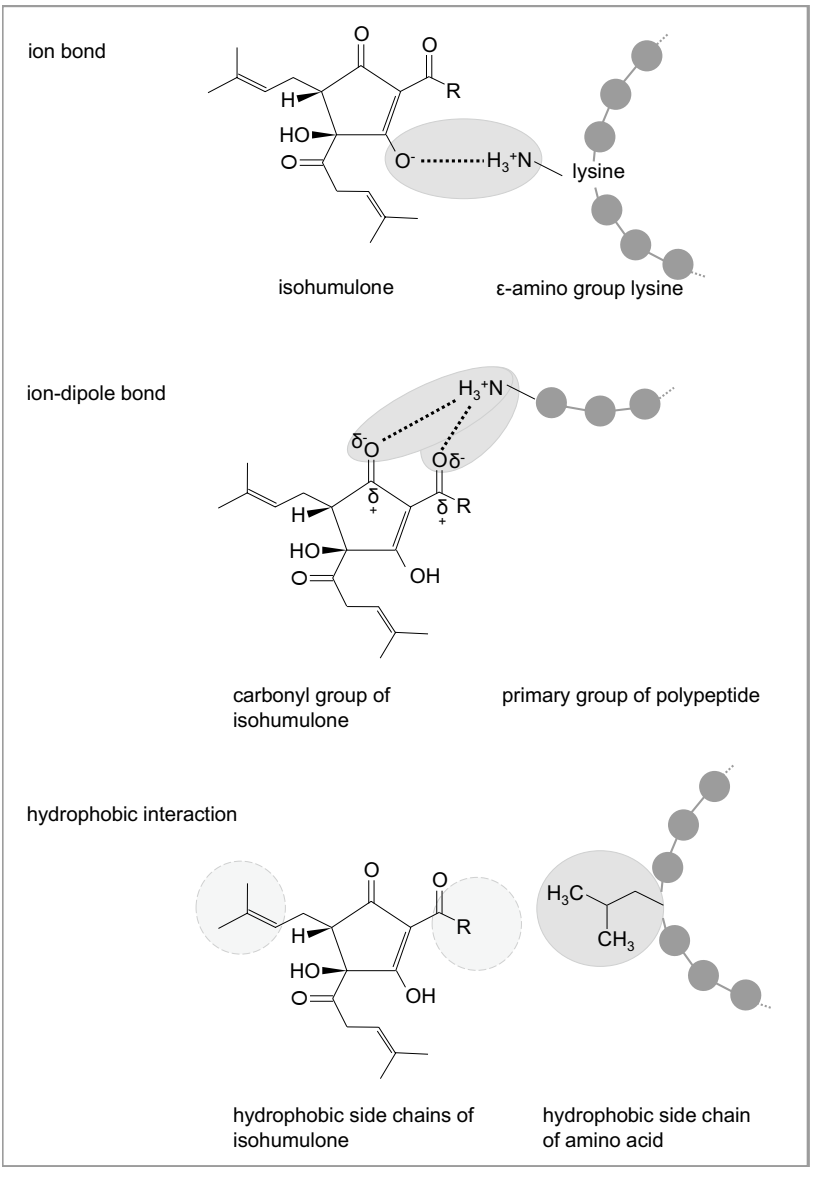

Fig. 1 Schematic overview of potential reactions between isohumulones (isohumulone, isoadhumulone and isocohumulon with their epimeric forms) and polypeptides/proteins $[9,11-13] . R$ is representative of the side chains. The dark grey circles with connecting lines represent the possible reactions

acids, which have already been described by other authors. Ionic bonds, ion-dipole bonds or hydrophobic interactions are possible [9-14]. Covalent bonds have not yet been found. Asano and Hashimoto $[9,11]$ reported that isohumulones electrostatically combine with higher and medium molecular weight proteins. The acidic groups of the isohumulone molecule bind with the $\varepsilon$-amino group of the lysine. Roberts [10] confirmed a weak interaction between isohumulones and beer proteins. According to Simpson and Hughes [12], the binding is based on an ion-dipole arrangement between the primary amino group of polypeptides and the carbonyl groups of iso- $\alpha$-acids. They also described that hydrophobic bonds between side chains of hop acids and hydrophobic amino acid residues of polypeptides have a foam stabilizing effect [12]. Molecular dynamic simulations with cisisocohumulones and barley lipid transfer protein according to Euston et al. [13] demonstrated that the bindings are based on hydrophobic interactions. In their study, there was no indication of the formation of ion-dipole bonds between the carbonyl and enolate groups of the hop acids and the amino groups of the proteins. Consequently, the authors are not consistent with their statements.

Brewers have two options to obtain isomerized $\alpha$-acids in the pitching wort. First, the $\alpha$-acids are dosed at the beginning of the wort boiling to get the highest possible conversion to iso- $\alpha$-acids and thus the bitterness in the beer. Second, the $\alpha$-acids can be isomerized simultaneously in low concentrated wort/water in a separate vessel or applied as already isomerized hop products. This means that the isomerized hop acids are dosed into the boiled wort. Unlike the first option, the heat precipitable proteins, like leucosin [15], are already present in the hot trub [16]. Aforementioned binding options between iso- $\alpha$-acids and proteins/ amino acids have been mainly investigated for beer foam. Therefore, the aim of the present work is to characterize the reaction behavior between iso- $\alpha$-acids and proteins or free amino acids of the wort, which have not been considered so far, to minimize the losses of hop bitter acids in the brewhouse.

For this purpose, a laboratory-scale experiment $(100 \mathrm{~mL})$ was performed in which the amino acids (arginine, glycine, leucine, lysine, methionine and valine), the dosing quantities of amino acids and iso- $\alpha$-acids, the temperature, the dosing time of iso- $\alpha$-acids as well as the reaction time were varied. Additionally, isothermal titration calorimetry (ITC) was performed with proline, lysine, glutamine and histidine to study the reaction behavior of amino acids with iso- $\alpha$ acids in detail. To gain an indication of the binding behavior between iso- $\alpha$-acids and proteins, laboratory experiments were performed with bovine serum albumin. Various temperatures as well as different dosing quantities of iso- $\alpha$-acids were investigated and the results were analyzed by HPLC. For characterization of the binding, an ITC was conducted. Last, to investigate the reaction behavior of a beer wort containing various proteins and free amino acids with iso- $\alpha$ acids, a series of experiments were performed with differently treated wort and determined by HPLC.

\section{Materials and methods}

\section{Sample preparation}

To investigate the binding ability of free amino acids with iso- $\alpha$-acids (Fig. 2, Part I), six amino acids were selected according to their occurrence in wort and the possibility of their free amino nitrogen (FAN) determination: arginine, glycine, leucine, lysine, methionine, and valine. The samples were prepared on a scale of $100 \mathrm{~mL}$ with deionized water. $2 \mathrm{mg} / \mathrm{L} \alpha$-amino nitrogen of the respective amino acids were weighed in with the equimolar ratio of iso- $\alpha$-acids. In the following, this ratio is given as 1:1 ( $\alpha$-amino nitrogen of amino 


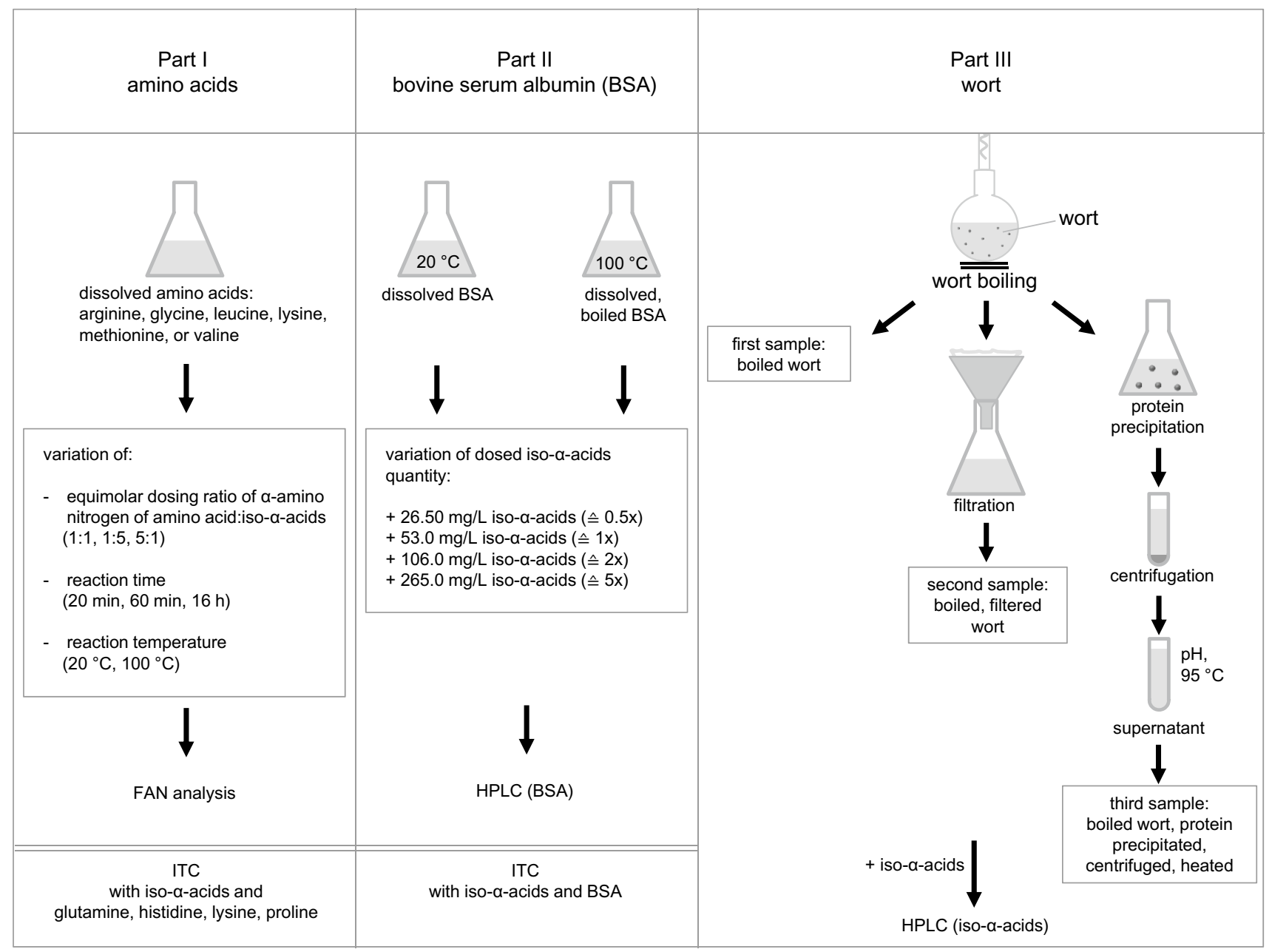

Fig. 2 Overview of experiments. BSA bovine serum albumin, FAN free amino nitrogen, HPLC High-Performance Liquid Chromatography, ITC isothermal titration calorimetry

acid:iso- $\alpha$-acids). The samples reacted for $20 \mathrm{~min}$ at $20^{\circ} \mathrm{C}$ and were determined in triplicate. To find out whether the reaction takes place in a different ratio, the ratios 1:5 and 5:1 and a variation of temperature $\left(100{ }^{\circ} \mathrm{C}\right)$ and time (20 min, $60 \mathrm{~min}$, $16 \mathrm{~h}$ ) with lysine were examined. Either the iso- $\alpha$-acids were added before or after the temperature treatment.

In the following, the calculation of the equimolar amount of iso- $\alpha$-acids to $2.0 \mathrm{mg} / \mathrm{L} \alpha$-amino nitrogen is shown using valine as an example. The quantity of valine weighed in corresponds to $1.673 \mathrm{mg} / 100 \mathrm{~mL}$ for getting $0.2 \mathrm{mg} / 100 \mathrm{~mL}$ $\alpha$-amino nitrogen, as the $\alpha$-amino group accounts $21.96 \%$ of the total molecule. According to Eq. 1 and the molar mass of valine of $117.15 \mathrm{~g} / \mathrm{mol}$, this results in an amount of substance of $14.28 \mu \mathrm{mol}$.

$n=\frac{m}{M}[17]$

where $n$ is the amount of substance, $m$ is the mass, and $M$ is the molar mass.
For the determination of the iso- $\alpha$-acids dosage, the calculated amount of substance is multiplied by the molar mass of the iso- $\alpha$-acids $(362.46 \mathrm{~g} / \mathrm{mol})$. Subsequently, according to the content of $30.31 \%$ in the Isohop ${ }^{\circledR}$ product, $100 \%$ calculated, resulting in $17.0 \mathrm{mg} / 100 \mathrm{~mL}$. For the multiplied quantities, the dosage was increased accordingly.

The binding capacity of proteins with iso- $\alpha$-acids was investigated using bovine serum albumin (BSA), see Fig. 2, Part II. For this purpose, two different tempering processes at $20^{\circ} \mathrm{C}$ and $100{ }^{\circ} \mathrm{C}$ as well as different iso- $\alpha$-acids dosings were performed. At $20^{\circ} \mathrm{C}$, BSA dissolved in deionized water was reacted with iso- $\alpha$-acids. At $100{ }^{\circ} \mathrm{C}$, the dissolved BSA was boiled under reflux for $60 \mathrm{~min}$ and then iso- $\alpha$-acids were added before it was cooled down and analyzed. In both approaches, the final concentration was $20 \mathrm{mg}$ BSA with $53.0 \mathrm{mg} / \mathrm{L}$ iso$\alpha$-acids per $100 \mathrm{~mL}$. These single substances as well the composite solution were analyzed using Resource Reversed Phase Liquid Chromatography (Resource RPC) and Size Exclusion High-Performance Liquid Chromatography (SE-HPLC). 
To observe the binding behavior of the protein mixture of wort (Fig. 2, Part III), a wort of a $100 \mathrm{~L}$ pilot plant $\left(12.1^{\circ} \mathrm{P}\right.$, $\mathrm{pH}$ 5.61) was boiled under reflux for $30 \mathrm{~min}$. All samples had a volume of $100.0 \mathrm{~mL}$ with a concentration of $49.0 \mathrm{mg} / \mathrm{L}$ iso- $\alpha$-acids. After adding the iso- $\alpha$-acids, the samples were cooled down in an ice bath before analysis. First sample: the iso- $\alpha$-acids were added to wort directly after the boiling time. Second sample: the wort was filtered through a folded filter before dosing the iso- $\alpha$-acids. Third sample: the proteins of the wort were precipitated with $20 \%$ trichloroacetic acid $(10 \mathrm{~mL}$ at $100 \mathrm{~mL}$ wort) in an ice bath for $20 \mathrm{~min}$. Furthermore, the sample was centrifuged at $3500 \mathrm{~g}$ for $20 \mathrm{~min}$ at $10{ }^{\circ} \mathrm{C}$ and the supernatant collected. After $\mathrm{pH}$ adjustment with $10 \mathrm{~N}$ potassium hydroxide solution to the original value, the sample was reheated to $95{ }^{\circ} \mathrm{C}$ before dosing the iso- $\alpha$-acids. All samples were determined fivefold and the confidence intervals were calculated with the associated t value (95\%).

\section{Wort preparation}

The wort production for the trials was done in the $100 \mathrm{~L}$ pilot plant of Anhalt University of Applied Sciences (Köthen (Anhalt), Germany). The repeatability of the system has been studied in a previous publication, where more detailed information on the system is given as well [18]. Premium Pilsner malt (95.5\%), Carahell (2.5\%) and sour malt (2.0\%) from Mich. Weyermann GmbH (Bamberg, Germany) was milled with a two-roller mill (Künzel Maschinenbau GmbH, Mainleus, Germany) set at a 0.7-mm roller distance. Mashing-in was performed with a water-to-grist ratio of 3.6:1 and started at $57{ }^{\circ} \mathrm{C} / 10 \mathrm{~min}$, followed by $63{ }^{\circ} \mathrm{C} / 35 \mathrm{~min}$, $72{ }^{\circ} \mathrm{C} / 20 \mathrm{~min}$, and $78^{\circ} \mathrm{C} / 5 \mathrm{~min}$. Wort separation was performed with a lauter tun.

\section{Reagents}

Isohop $^{\circledR}$ (containing $30.31 \%$ iso- $\alpha$-acids) was obtained from BarthHaas UK Ltd. (Tonbridge, United Kingdom). Disodium hydrogen phosphate dihydrate $(\geq 99.5 \%)$, di-sodium hydrogen phosphate dodecahydrate $(\geq 99 \%)$, DL-methionine ( $\geq 98 \%$ ), ethanol (96\%), methanol ROTISOLV ${ }^{\circledR}$ HPLC gradient, L-histidine CELLPURE ${ }^{\circledR}(\geq 99 \%)$, L-glutamine CELLPURE $^{\circledR}(\geq 99 \%)$, ortho-phosphoric acid $(\geq 85 \%)$, potassium dihydrogen phosphate $(\geq 98 \%)$, potassium hydroxide ( $\geq 85 \%)$, sodium dihydrogen phosphate dihydrate $(\geq 99 \%)$ and trifluoroacetic acid were purchased from Carl Roth GmbH \& Co. KG (Karlsruhe, Germany). Acetonitrile gradient grade for liquid chromatography LiChrosolv ${ }^{\circledR}$, albumin fraction $\mathrm{V}$ (from bovine serum) ( $\geq 97 \%), \mathrm{D}(-)$-fructose, glycine (for analysis), ninhydrin (ACS, Reag. Ph Eur), potassium iodate (ACS, ISO, Reag. Ph Eur), and trichloroacetic acid (for analysis) were obtained from Merck KGaA
(Darmstadt, Germany). L( +)-arginine ( $\geq 98 \%)$, L( +)-leucine $(\geq 99 \%), \mathrm{L}(+)$-lysine $(\geq 98 \%), \mathrm{L}(+)$-proline $(99 \%)$, and $\mathrm{L}(+)$-valine $(\geq 99 \%)$ were supplied from Thermo Fisher $\mathrm{GmbH}$ (Kandel, Germany). All solutions were made with deionized water (Milli- ${ }^{\circledR}$ ) and prepared daily.

\section{Analyses}

The free amino nitrogen (FAN) was determined according to MEBAK 2.6.4.1.1 (EBC) [19]. Where the extinction was measured with UV/VIS Spectrophotometer V-530 from JASCO Labor- und Datentechnik GmbH Deutschland (Gross-Umstadt, Germany). A standard was prepared for each amino acid and the value was utilized to calculate the FAN value. To verify the accuracy of the analysis, a calibration was performed for each amino acid. As an example, $R^{2}$ was 0.9985 for glycine and 0.9979 for lysine.

Determination of iso- $\alpha$-acids by High-Performance Liquid Chromatography (HPLC): chromatography was performed with an Agilent 1100 Series Capillary LC System with a Diode-Array-Detector from Agilent Technologies, Inc. (Santa Clara, United States) at a temperature of $40{ }^{\circ} \mathrm{C}$ and a flow rate of $0.5 \mathrm{~mL} / \mathrm{min}$. An injection volume of $10 \mu \mathrm{L}$ was applied for iso- $\alpha$-acids analysis. Mobile phase B consisted of $75 \%$ methanol, $24 \%$ deionized water and $1 \%$ phosphoric acid (85\%). The elution rate was isocratic at $100 \% \mathrm{~B}$ for 25 min. A Nucleodur ${ }^{\circledR} 100-5$ C18 EC 125/4 from Machery-Nagel GmbH \& Co. KG (Düren, Germany) was selected for separation. Iso- $\alpha$-acids were measured at $270 \mathrm{~nm}$.

Determination of albumin by Resource Reversed Phase Liquid Chromatography (Resource RPC): A LaChrom Elite ${ }^{\circledR}$ L-2455 equipped with a Diode-Array-Detector from VWR International (Radnor, United States) was utilized for chromatography with a flow rate of $1 \mathrm{~mL} / \mathrm{min}$, a temperature of $35^{\circ} \mathrm{C}$ and an injection volume of $40 \mu \mathrm{L}$. Two mobile phases were applied (A and B) with A composed of $0.1 \%$ trifluoroacetic acid in water and $\mathrm{B}$ with $90 \%$ acetonitrile with $0.1 \%$ (v:v) trifluoroacetic acid. The elution started with $80 \%$ of mobile phase A for the first 6 min followed by $60 \%$ for the next $7 \mathrm{~min}$, followed by $7 \mathrm{~min} 55 \%$ mobile phase A, 6 min $50 \%, 5 \mathrm{~min} 30 \%$ and $3 \mathrm{~min} 0 \%$, before mobile phase A was increased again to $80 \%$ for $7 \mathrm{~min}$. A Resource ${ }^{\mathrm{TM}} \mathrm{RPC} 1 \mathrm{~mL}$ from GE Healthcare Bio-Sciences AB (Uppsala, Sweden) was selected for separation. Specifically, a wavelength of $214 \mathrm{~nm}$ was utilized.

Determination of albumin by Size Exclusion High-Performance Liquid Chromatography (SE-HPLC): The size exclusion was performed with a LaChrom Elite ${ }^{\circledR}$ L-2455 from VWR International (Radnor, United States) at a temperature of $25^{\circ} \mathrm{C}$ and a flow rate of $1.0 \mathrm{~mL} / \mathrm{min}$. An injection volume of $10 \mu \mathrm{L}$ was applied. The elution rate was isocratic at $100 \%$ $150 \mathrm{mM}$ sodium phosphate buffer for $30 \mathrm{~min}$. A BioSep ${ }^{\mathrm{TM}}$ $5 \mu \mathrm{m}$ SEC-s2000 $145 \AA$, LC Column from Phenomenex 
Ltd. Deutschland (Aschaffenburg, Germany) was selected for separation. BSA were measured with a Diode-ArrayDetector at $214 \mathrm{~nm}$.

The isothermal titration calorimetry (ITC) was performed on a MicroCal PEAQ-ITC from Malvern Panalytical Ltd, Malvern, Worcestershire (United Kingdom). Isohop ${ }^{\circledR}$ was diluted with Milli-Q water to a concentration of 5 or $2 \mathrm{mM}$, while BSA was dissolved and diluted to a concentration of $50 \mu \mathrm{M}$ and the diverse amino acids to $500 \mu \mathrm{M}$. All diluted substances were filled in the sample cell. Milli-Q water was utilized as control solution. The following settings were valid for the ITC runs: $25^{\circ} \mathrm{C}, 10 \mu \mathrm{cal} / \mathrm{s}, 750 \mathrm{rpm}$ stirring speed, with an injection spacing of $150 \mathrm{~s}$ and an injection time of $6 \mathrm{~s}$. The method was set up to make a single injection of $0.4 \mu \mathrm{L}$, followed by $12.3 \mu \mathrm{L}$ injections.

\section{Results and discussion}

In the first step of the test series, the reaction behavior between amino acids and iso- $\alpha$-acids were investigated. Asano and Hashimoto [9] postulated that iso- $\alpha$-acids bind to foam proteins via the $\varepsilon$-amino group of lysine. Furthermore, the authors found that especially higher and medium molecular fractions bind to iso- $\alpha$-acids, since the concentration of $\varepsilon$-amino groups in these fractions is higher [11]. Based on the study carried out on beer foam by Asano and Hashimoto, lysine was initially selected as the reaction partner in this laboratory experiment, as the acidic iso- $\alpha$-acids interact with basic substances [9]. The first aim was to find out whether free amino acids behave in a similar way as in a bound status in a protein and bind to iso$\alpha$-acids. For this purpose, the equimolar amount of $\alpha$-amino nitrogen in form of lysine and iso- $\alpha$-acids, as already described above, was treated in aqueous solution at $100{ }^{\circ} \mathrm{C}$ and different reaction times. In addition, the concentration of the substances was increased individually (1:5 and 5:1 lysine:iso- $\alpha$-acids) and the iso- $\alpha$-acids were once added only after the temperature treatment of the amino acid (Fig. 7). The results of the FAN determination suggest that the iso- $\alpha$-acids do not bind to free lysine. Neither at the shorter reaction time of $20 \mathrm{~min}$ nor at $60 \mathrm{~min}$. The results of dosing the iso- $\alpha$-acids after the temperature treatment of the amino acid also showed no significant effect. However, it cannot be excluded that the two reaction partners initially interact via a non-covalent bond, which is broken by the temperature treatment. In this case, however, this bond would not be relevant in the brewhouse either, as temperatures around $100^{\circ} \mathrm{C}$ are also present there. As an extension of the tests, they were also performed $20 \mathrm{~min} / 16 \mathrm{~h}$ at $20{ }^{\circ} \mathrm{C}$ instead of $20 \mathrm{~min} / 60 \mathrm{~min}$ at $100^{\circ} \mathrm{C}$. The results gave any new information.

To investigate the effect of iso- $\alpha$-acids on other amino acids with different isoelectric points, the amino acids arginine, glycine, methionine, leucine and valine were investigated. The selection of the amino acids was according to their occurrence in the preboil wort. It should be noted that proline has the highest concentration in preboil wort [20], but was not included because of the used method. Moreover, the simplest amino acid (glycine) and a sulphur-containing amino acid (methionine) were chosen. According to the isoelectric points, the amino acids are present in aqueous solution as cation, dipolar ion or anion, depending on the $\mathrm{pH}$ value. Thus, in the sample solution with $\mathrm{pH} 6.70$, the amino acids glycine, leucine, methionine and valine had a positive total net charge, since the dissociation of the acid group decreased. The amino acids arginine and lysine had a negative total charge, because the dissociation of the acid increased and the amino group released the hydrogen ion [21]. Hence, the possible charge differences were taken into account.

As the temperature and time did not show any influence in the investigation of lysine and iso- $\alpha$-acids in the first step, other amino acids and iso- $\alpha$-acids were examined the same way at $20^{\circ} \mathrm{C}$ for $20 \mathrm{~min}$. The results revealed no significant change in the measured FAN content compared to added FAN of $2.00 \mathrm{mg} / \mathrm{L}$. To have an analytical comparison, the samples were examined for iso- $\alpha$-acids by HPLC to validate a decrease. There was no reaction detected.

In the ITC experiments, the amino acids glutamine, histidine, lysine, and proline were tested at a concentration of $500 \mu \mathrm{M}$ (10 times higher than BSA) to achieve appropriate stoichiometry. No significant heat changes were observed for any of the amino acids tested, indicating that there is no binding of iso- $\alpha$-acids to the individual amino acids. Thus, the results confirm the FAN analyses. According to the findings, free amino acids in the wort have no influence on the hop yield in the brewhouse.

Further experiments were intended to provide information on the extent of how the proteins can combine with iso- $\alpha$-acids. Barley malt proteins in beer wort are classified according to Osborne into albumins, globulins, prolamins (hordeins) and glutelins. Globulins dissolve in salt solutions and coagulate above $90^{\circ} \mathrm{C}$, prolamines (hordeins) decrease during the malting process and are soluble in alcohol, and glutelins that can be dissolved in alkaline solutions [21-24]. Therefore, they were excluded for the test series due to the solvent properties of the model solution. Albumins include the protein $\mathrm{Z}$ and the lipid transfer proteins LTP1 and LTP2, which marginally change during the brewing process compared to other proteins and can tolerate temperatures of up to $100{ }^{\circ} \mathrm{C}$. They contribute to the quality of the beer foam and beer turbidity [24-29].

Before the specific beer wort was investigated, the reaction behavior of albumin was examined in a preliminary test. The aim was to show the reaction differences between the protein denatured by heat and the protein present at room temperature. 
Therefore, a boiled and an unboiled, dissolved bovine serum albumin (BSA) $(20 \mathrm{mg}$ ) was combined, respectively, with different quantities of iso- $\alpha$-acids in $100 \mathrm{~mL}$ deionized water at $20{ }^{\circ} \mathrm{C}$ and $100{ }^{\circ} \mathrm{C}$ before the sample was examined for albumin concentration by Resource RPC and SE-HPLC. The combination of the iso- $\alpha$-acids with the BSA shows an altered peak area, since the compound molecule reacts differently during size exclusion and the diode array detector thus detects different signals. Figure 3 presents the evaluated peak areas of the Resource RPC. Based on the BSA standard with $20 \mathrm{mg} / 100 \mathrm{~mL}$ (100\%), significant differences between the various samples of the reaction temperatures of $20^{\circ} \mathrm{C}$ and $100{ }^{\circ} \mathrm{C}$ can be seen. At $20^{\circ} \mathrm{C}$, a noticeable increase in peak area of $22 \%$ is visible for the sample $20 \mathrm{mg} \mathrm{BSA}+1 \times$ IAA $(53.0 \mathrm{mg} / \mathrm{L}$ iso- $\alpha$-acids). The other samples do not show a clear change. The samples, where the bovine serum albumin was boiled for $60 \mathrm{~min}$ and the iso- $\alpha$-acids were added into the still hot solution, show significant variations between the different dosages. With the addition of more iso- $\alpha$-acids, the increase in peak area is greater. However, between two-fold (106 mg/L) and five-fold $(265 \mathrm{mg} / \mathrm{L})$ iso- $\alpha$-acids quantity the peak area decreases. In case of saturation, a plateau ought to remain.

Figure 4 presents the SE-HPLC results divided in BSA monomer, dimer and trimer to make a distinction. The BSA tends to aggregation under stress conditions, e.g. at higher temperatures [30, 31]. Noticeable are the increases in the peak areas from BSA monomer to dimer to trimer, which shows the most significant changes with a 1.8-fold peak area compared to the BSA standard. As a result, the trimeric BSA reacts most effectively with the iso- $\alpha$-acids. Murayama and Tomida [32] revealed that heating BSA above $57^{\circ} \mathrm{C}$ causes

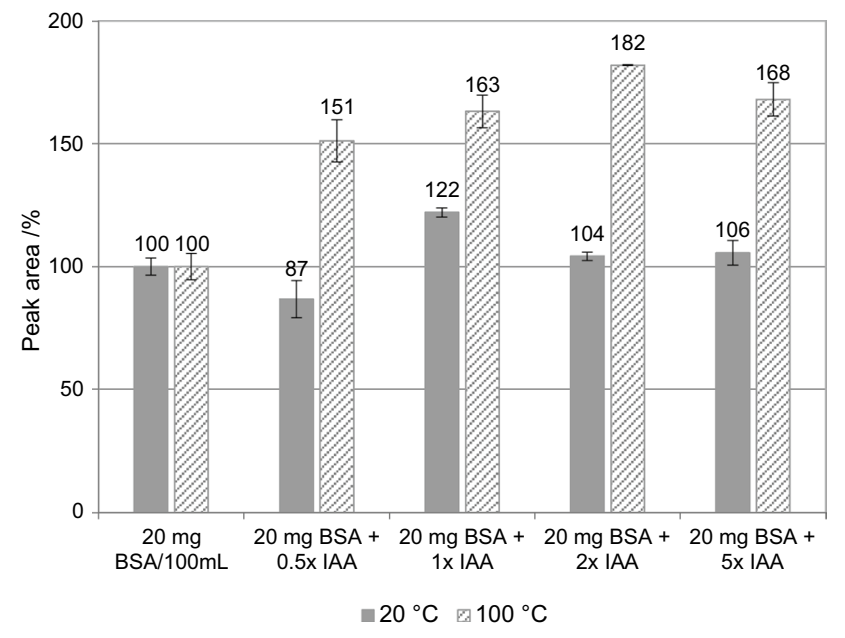

Fig. 3 Change in bovine serum albumin (BSA) peak areas measured by Reversed Phase Liquid Chromatography (RPC) when varying the iso- $\alpha$-acids (IAA) dosing quantity at $20{ }^{\circ} \mathrm{C}$ and $100{ }^{\circ} \mathrm{C}$. The standard with $20 \mathrm{mg} / 100 \mathrm{~mL}$ BSA equals $100 \%$. " $1 \times$ ” corresponds to $53.0 \mathrm{mg} / \mathrm{L}$ iso- $\alpha$-acids. The error bars correspond to the standard deviation. $n=2$

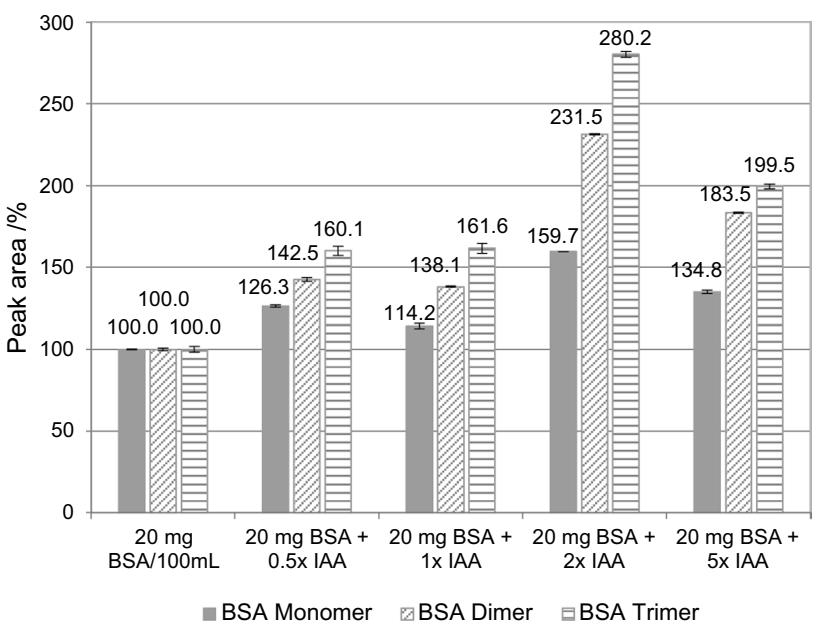

Fig. 4 Change in bovine serum albumin (BSA) peak areas measured by Size Exclusion High-Performance Liquid Chromatography (SEHPLC) when varying the iso- $\alpha$-acids (IAA) dosing quantity at the reaction temperature of $100{ }^{\circ} \mathrm{C}$. The standard with $20 \mathrm{mg} / 100 \mathrm{~mL}$ BSA corresponds to $100 \%$. " $1 \times$ " corresponds to $53.0 \mathrm{mg} / \mathrm{L}$ iso- $\alpha$ acids. Division of BSA into monomer, dimer and trimer. The error bars correspond to the standard deviation. $n=2$

the tertiary structure to be lost and that irreversible intermolecular $\beta$-sheets are formed above $70{ }^{\circ} \mathrm{C}$. Thus, a structural change is present, which corresponds an aggregation or trub formation in the brewhouse.

Figures 3 and 4 show the clear differences in reaction behavior between the protein denatured by heat and the protein present at room temperature. However, it reveals that the protein present at $20^{\circ} \mathrm{C}$ undergoes a reaction apparently with the iso- $\alpha$-acids. An isothermal titration calorimetry (ITC) was performed to investigate the reaction behavior in the room temperature range more closely. This could provide information on how non-heat precipitable proteins react, as they are present in their original form. ITC examines chemical reactions quantitatively and helps to describe them thermodynamically. The isothermal titration calorimeter is very sensitive, even the slightest temperature changes can be detected and thus determine either endothermic or exothermic reaction behavior of the reactants or their binding characteristics [33].

Figure 5 represents the binding thermogram of the iso$\alpha$-acids (fresh) bond to BSA, with all background heat removed. The sigmoidal curve is adaptable to a One Set of Sites model to obtain accurate affinities and thermodynamics. A stoichiometry of 1.13 suggests a $1: 1$ binding. The low standard errors for stoichiometry $(\mathrm{N})$, binding affinity $(\mathrm{KD})$ and binding enthalpy $(\Delta \mathrm{H})$ indicate a good fit. Further comparison revealed that enthalpic and entropic forces drive the binding equally. The relatively high value of the binding enthalpy compared to other similar analyses of small molecules binding to proteins and the 1:1 binding, suggest that specific electrostatic (ionic) interactions take 

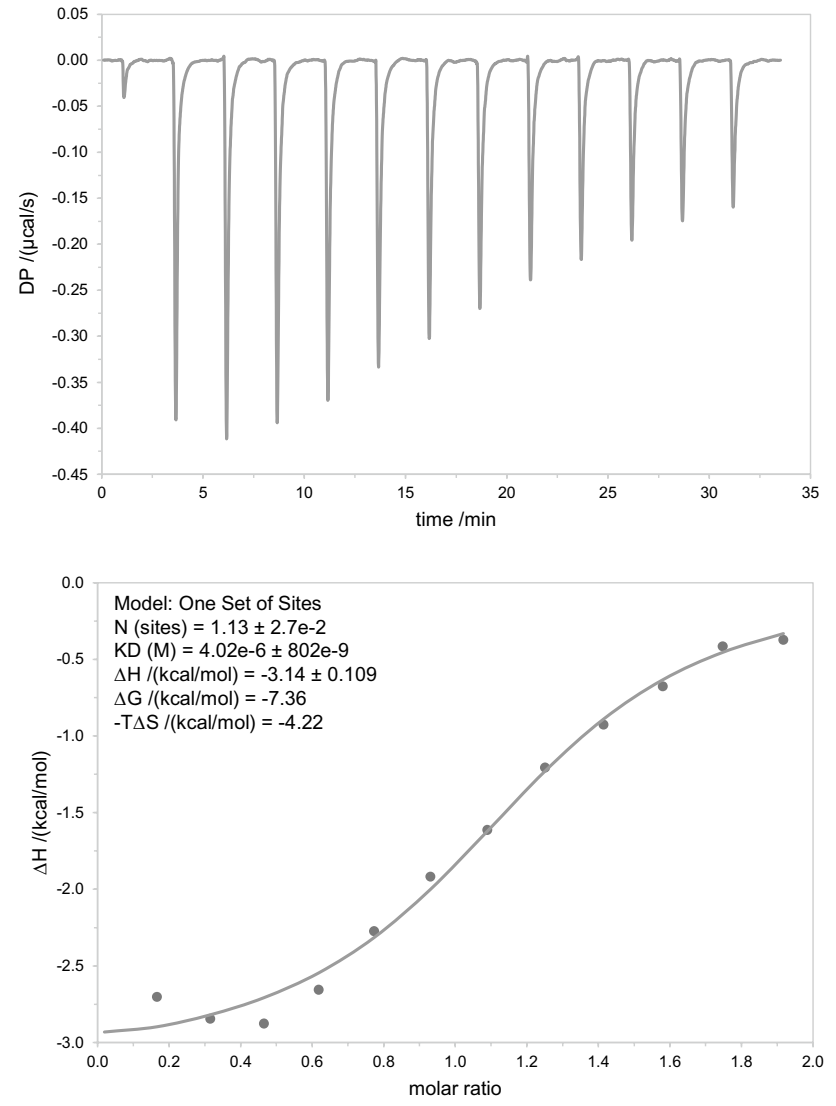

Fig. 5 Binding thermogram of iso- $\alpha$-acids binding to bovine serum albumin. $D P$ difference heating power, $N($ sites $)$ stoichiometry, $K D$ binding affinity, $\Delta H$ binding enthalpy, $\Delta G$ Gibbs free energy, $T$ temperature, $\Delta S$ entropy

place and that the binding of iso- $\alpha$-acids to BSA is not just caused by hydrophobic interaction.

Table 1 presents the ITC results of the reaction behavior of BSA to iso- $\alpha$-acids and iso- $\alpha$-acids cold stored for 9 months. About $7 \%$ of the iso- $\alpha$-acids changed structurally by oxidation or degraded to humulinic acids during cold storage. The results of the stored iso- $\alpha$-acids show a shift of the ionic interactions, represented by the enthalpy signal, towards hydrophobic interactions, revealing entropy. Whereas the stoichiometry shifts to a 1:6 binding.

Depending on the degree of oxidation or degradation of the hop bitters, a different reaction behavior is probably observed: ionic reactions, as postulated by Asano and Hashimoto [9, 11] as well as Simpson and Hughes [12] for beer foam, and hydrophobic interactions, as demonstrated by Euston [13].

Since not all proteins precipitate due to heat, the results indicate that the heat-stable proteins must be responsible for the losses of hop bitter substances when hops are added to a boiled, unhopped wort. To determine this, a pilsner beer wort

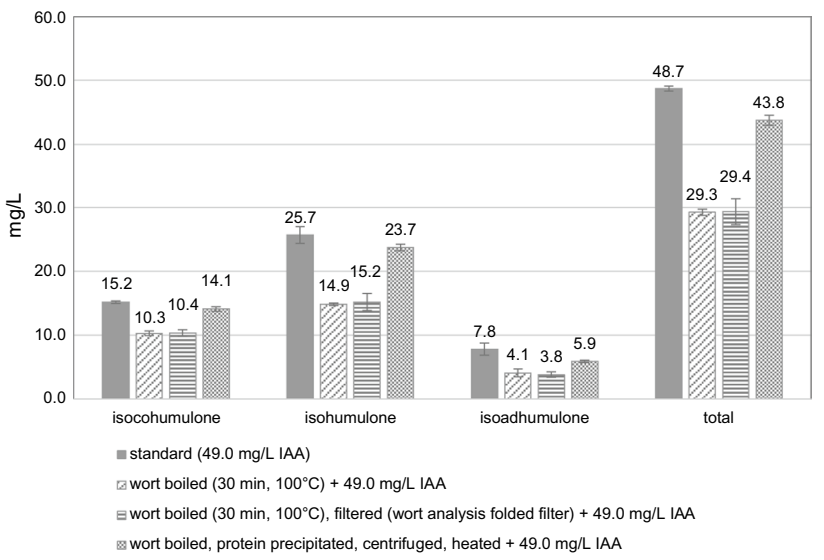

Fig. 6 Change in the iso- $\alpha$-acids composition of a differently treated wort from a $100 \mathrm{~L}$ pilot plant. The error bars indicate the confidence intervals and were calculated with the associated $t$ value (95\%). IAA iso- $\alpha$-acids. $n=5$

was selected and investigated due to the complex protein composition of wort. For this purpose, the wort from a $100 \mathrm{~L}$ pilot brewery was boiled for $30 \mathrm{~min}$ in the laboratory. After different treatments (filtration and protein precipitation), $49.0 \mathrm{mg} / \mathrm{L}$ iso$\alpha$-acids were added and the sample was immediately cooled down in an ice bath and analyzed for iso- $\alpha$-acids by HPLC. Figure 6 shows the results of the experiments. In comparison to the iso- $\alpha$-acids standard $(49.0 \mathrm{mg} / \mathrm{L}$ iso- $\alpha$-acids in deionized water), there was a significant reduction of iso- $\alpha$-acids in the samples. Especially, isohumulone showed losses of up to $42 \%$ and isoadhumulone up to $51 \%$. It should be noted that the lower values show a larger error in relation. For isocohumulone, a reduction of up to $32 \%$ was observed. Irwin et al. [3] pointed to increased losses of the unisomerized forms humulone and adhumulone during wort boiling. Similarly, Briggs et al. [34] reported that the utilization of humulone (pKa 5.5) and adhumulone (pKa 5.7) is slower in the wort due to a more ionized cohumulone (pKa 4.7). In contrast, Malowicki and Shellhammer [35] revealed that the isomerization rate of cohumulone is similar to that of humulone and adhumulone. The experiments of Jaskula et al. [4] also demonstrated a predominant loss of isohumulone and isoadhumulone during brewing, especially to the hot trub. In the present test series, the iso- $\alpha$-acids were added to the wort after heat treatment so that the hot trub had already precipitated. The samples with the boiled and the boiled, filtered wort do not differ significantly in their isocohumulone, isohumulone and isoadhumulone contents. Consequently, already precipitated proteins (treated with $20 \%$ trichloroacetic acid) can no longer react with iso- $\alpha$-acids. However, the sample with the precipitated protein differs significantly from other two treatments; the values of total iso- $\alpha$-acids are about $49 \%$ higher. Despite this, about $10 \%$ of the iso- $\alpha$-acids are still missing compared to the standard. An explanation for this could 
be, that the dosed amount of trichloroacetic acid was not sufficient, because a proportion of $10 \%$ trichloroacetic acid (20\%) was added, especially since $20 \%$ of the acid was applied in a previous work [36], so that only half the proteins were precipitated. On the other hand, the trichloroacetic acid can precipitate proteins in disordered or unfolded structure less well, so that some of the proteins could not be denaturated and precipitated $[37,38]$. However, a review of the trichloroacetic acid dosage did not reveal elevated levels of iso- $\alpha$-acids. Nevertheless, the proteins that are still in solution after the heat treatment react with the iso- $\alpha$-acids. Although they are not involved in the trub formation in the present series of experiments, the losses of iso- $\alpha$-acids are, as shown by Jaskula et al. [4], mainly found for isohumulone and isoadhumulone. This indicates that isohumulone and isoadhumulone react with proteins to a greater extent than isocohumulone.

Hanke et al. [39] revealed with their experiments that the bitter acids are partly subject to still unknown degradation reactions and that the losses due to these reactions are significantly higher than the losses due to hot trub formation. The degradation reactions are also described in other publications [35]. Combining the knowledge gained from the experiments carried out, the question arises whether there is another reason for the reduction of iso- $\alpha$-acids besides the degradation reactions and the losses to the hot trub. There were no differences in iso- $\alpha$-acids concentration between the samples with trub and without trub. However, a much smaller reduction of iso$\alpha$-acids was found when some of the proteins still in solution after heat treatment were also reduced. Consequently, the iso$\alpha$-acids bind to non-heat precipitable proteins, corresponding to the foam proteins. The bonds between the two substances were discussed by several authors $[9,11,12]$. If the bonds withstand the fermentation process, some of the iso- $\alpha$-acids would only be a loss of bitterness but not a general loss, as an improvement in beer foam may be the result. This needs to be proven in further experiments.

\section{Conclusion}

The experiments revealed that free amino acids are not involved in the reactions that lead to losses of iso- $\alpha$-acids in the brewhouse. In contrast to that, the experiments showed that proteins are mainly responsible for the reduction of iso- $\alpha$-acids, even independently of the formation of hot trub. More precisely, the proteins that do not precipitate due to temperature and are still in solution after boiling react there depending on the degree of oxidation or degradation of the hop bitter substances. The proteins that are already precipitated in the trub will no longer react with the iso- $\alpha$-acids. In future experiments, it should be investigated whether the bindings between albumin fractions
Table 1 Comparison of ITC results of the reaction behavior of bovine serum albumin with iso- $\alpha$-acids (fresh) and nine months cold stored iso- $\alpha$-acids

\begin{tabular}{lll}
\hline & Fresh & $\begin{array}{l}\text { After 9 months cold } \\
\text { storage }\end{array}$ \\
\hline$N($ sites $)$ & $1.13 \pm 2.7 \mathrm{e}-2$ & $6.25 \pm 0.391$ \\
$K D(\mathrm{M})$ & $4.02 \mathrm{e}-6 \pm 802 \mathrm{e}-9$ & $53.5 \mathrm{e}-6 \pm 23.6 \mathrm{e}-6$ \\
$\Delta H /(\mathrm{kcal} / \mathrm{mol})$ & $-3.14 \pm 0.109$ & $0.880 \pm 0.119$ \\
$\Delta G /(\mathrm{kcal} / \mathrm{mol})$ & -7.36 & -5.83 \\
$-T \Delta S /(\mathrm{kcal} / \mathrm{mol})$ & -4.22 & -4.95 \\
\hline
\end{tabular}

$N($ sites ) stoichiometry, $K D$ binding affinity, $\Delta H$ binding enthalpy, $\Delta G$ Gibbs free energy, $T$ temperature, $\Delta S$ entropy

(protein $\mathrm{Z}$ and LTP1/2) and iso- $\alpha$-acids, which are formed in the brewhouse, are maintained via the fermentation process. This means that, depending on the hop dosing time, the iso- $\alpha$-acids lost in the brewhouse during wort preparation would actually not be completely lost via the trub, but the iso- $\alpha$-acids form the already confirmed bonds in the later beer foam together with the proteins. Consequently, there is no loss of the iso- $\alpha$-acids. The recorded reduction in hop yield corresponds to the promotion of the final beer foam. In a future series of experiments, it would have to be investigated whether there are sensory differences between the dissolved iso- $\alpha$-acids and the iso- $\alpha$-acids that bind to the proteins still in solution after wort boiling.

\section{Appendix}

See Fig. 7.

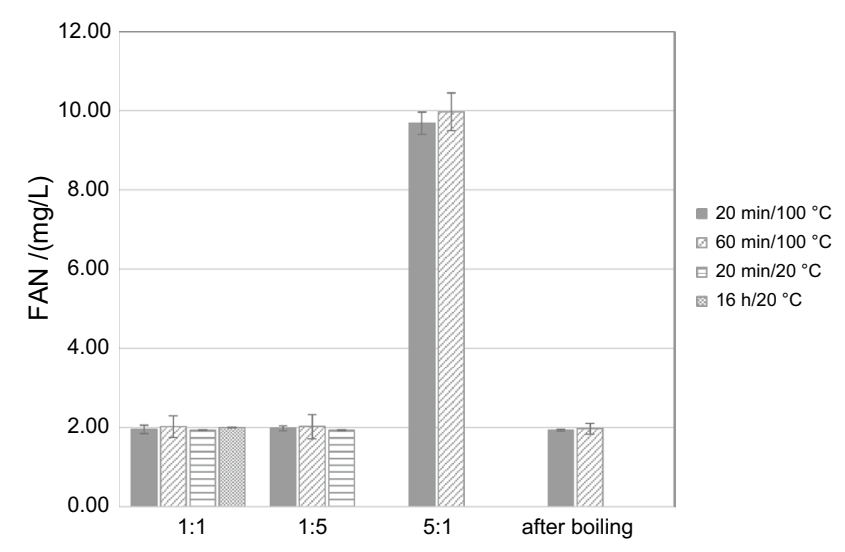

Fig. 7 Reaction of lysine with iso- $\alpha$-acids at different dosages, times and temperatures in aqueous solution. Quantity ratio $=\alpha$-amino nitrogen of lysine:iso- $\alpha$-acids. After boiling means, that the dosing of the iso- $\alpha$-acids was after the heat treatment of the amino acid. The error bars correspond to the confidence intervals and were calculated with the associated $t$ value (95\%). $n=3$ 
Acknowledgements A special thank you for Ilona Jawinski and Christin Fischer from the Anhalt University of Applied Sciences, who supported the FAN and HPLC experiments. In addition, many thanks go to Malvern Panalytical GmbH and Concept Life Sciences Limited, who conducted and advised the ITC.

Funding Open Access funding enabled and organized by Projekt DEAL.

\section{Declarations}

Conflict of interest The authors have no conflicts of interest to declare that are relevant to the content of this article.

Compliance with ethics requirements This study does not contain any studies with human participants or animals performed by any of the authors.

Open Access This article is licensed under a Creative Commons Attribution 4.0 International License, which permits use, sharing, adaptation, distribution and reproduction in any medium or format, as long as you give appropriate credit to the original author(s) and the source, provide a link to the Creative Commons licence, and indicate if changes were made. The images or other third party material in this article are included in the article's Creative Commons licence, unless indicated otherwise in a credit line to the material. If material is not included in the article's Creative Commons licence and your intended use is not permitted by statutory regulation or exceeds the permitted use, you will need to obtain permission directly from the copyright holder. To view a copy of this licence, visit http://creativecommons.org/licenses/by/4.0/.

\section{References}

1. Spetsig L-O, Norman N, Viervoll H et al (1958) On the rearrangement products of humulone. Acta Chem Scand 12:592-593. https://doi.org/10.3891/acta.chem.scand.12-0592

2. Verzele M (1986) Centenary review: 100 years of hop chemistry and its relevance to brewing. J Inst Brew 92:32-48. https://doi. org/10.1002/j.2050-0416.1986.tb04372.x

3. Irwin AJ, Murray CR, Thompson DJ (1985) An investigation of the relationships between hopping rate, time of boil, and individual $\alpha$-acid utilization. J Am Soc Brew Chem 43:145-152. https:// doi.org/10.1094/ASBCJ-43-0145

4. Jaskula B, Goiris K, Van Opstaele F et al (2009) Hopping technology in relation to $\alpha$-acids isomerization yield, final utilization, and stability of beer bitterness. J Am Soc Brew Chem 67:44-57. https://doi.org/10.1094/ASBCJ-2009-0106-01

5. Spetsig LO (1968) The bitter substances of spent hops, trub, and yeast cover; a chromatographic study. J Inst Brew 74:346-351

6. Specht W (1952) Zur Extraktion von Hopfenbitterstoffen durch Ultraschall. Z Lebensm Unters Forsch 94:157-166

7. Howard GA, Slater CA (1957) Utilization of humulone and cohumulone in brewing. J Inst Brew 63:478-482

8. Brenner MW, Vigilante C, Owades JL (1956) A study of hop bitters (Isohumulones) in beer. Proc Annu Meet Am Soc Brew Chem 14:48-61. https://doi.org/10.1080/00960845.1956.12006476

9. Asano K, Hashimoto N (1976) Contribution of hop bitter substances to head formation of beer. Rept Res Lab Kirin Brew Co Ltd 19:9-16

10. Roberts RT (1976) Interaction between beer protein and isohumulone. J Inst Brew 82:282
11. Asano K, Hashimoto N (1980) Isolation and characterization of foaming proteins of beer. J Am Soc Brew Chem 38:129-137. https://doi.org/10.1094/ASBCJ-38-0129

12. Simpson WJ, Hughes PS (1994) Stabilization of foams by hopderived bitter acids. Chemical interactions in beer foam. Cerevisia Biotechnol 19:39-44

13. Euston SR, Hughes P, Naser MA et al (2008) Molecular dynamics simulation of the cooperative adsorption of barley lipid transfer protein and cis-isocohumulone at the vacuum-water interface. Biomacromol 9:3024-3032. https://doi.org/10.1021/bm8004325

14. Lu Y, Bergenståhl B, Nilsson L (2020) Interfacial properties and interaction between beer wort protein fractions and iso-humulone. Food Hydrocolloids 103:105648. https://doi.org/10.1016/j.foodh yd.2020.105648

15. Steiner E, Gastl M, Becker T (2011) Protein changes during malting and brewing with focus on haze and foam formation: a review. Eur Food Res Technol 232:191-204. https://doi.org/10. 1007/s00217-010-1412-6

16. Bastgen N, Becher T, Drusch S et al (2021) Usability and technological opportunities for a higher isomerization rate of $\alpha$-acids-a review. J Am Soc Brew Chem 79:17-25. https://doi.org/10.1080/ 03610470.2020 .1840893

17. Mortimer CE, Müller U (2010) Chemie, 10, überarb. Thieme, Stuttgart

18. Bastgen N, Ginzel M, Titze J (2019) Precision of a small brew house by determining the repeatability of different brews to guarantee the product stability of the beer. Beverages 5:67. https://doi. org/10.3390/beverages5040067

19. Mitteleuropäische Brautechnische Analysenkommission (2013) MEBAK - Wort, Beer, Beer-based Beverages: Collection of brewing analysis methods of the Mitteleuropäische Brautechnische Analysenkommission. Self-published by MEBAK, Freising

20. Wittmann R, Eichner K (1989) Nachweis von Maillard-Produkten in Malzen, Bieren und Braucouleuren. Z Lebensm Unters Forsch 188:212-220

21. Belitz H-D, Grosch W, Schieberle P (2009) Food Chemistry, 4th revised and extended. Springer, Berlin

22. Weiss W, Postel W, Görg A (1992) Application of sequential extraction procedures and glycoprotein blotting for the characterization of the 2-D polypeptide patterns of barley seed proteins. Electrophoresis 13:770-773

23. Görg A, Postel W, Weiss W (1992) Detection of polypeptides and amylase isoenzyme modifications related to malting quality during malting process of barley by two-dimensional electrophoresis and isoelectric focusing with immobilized $\mathrm{pH}$ gradients. Electrophoresis 13:759-770

24. Narziss L, Back W (2012) Die Bierbrauerei: Die Technologie der Würzebereitung, 8., überarb. und erg. Aufl. Die Bierbrauerei, Band 2. Wiley-VCH, Weinheim

25. Hejgaard J (1977) Origin of a dominant beer protein immunochemical identity with a $\beta$-amylase-associated protein from barley. J Inst Brew 83:94-96. https://doi.org/10.1002/j.2050-0416.1977. tb06422.x

26. Perrocheau L, Bakan B, Boivin P et al (2006) Stability of barley and malt lipid transfer protein 1 (LTP1) toward heating and reducing agents: relationships with the brewing process. J Agric Food Chem 54:3108-3113. https://doi.org/10.1021/jf052910b

27. Sørensen SB, Bech LM, Muldbjerg M et al (1993) Barley lipid transfer protein 1 is involved in beer foam formation. Tech Q Master Brew Assoc 30:136-145

28. Lusk LT, Goldstein H, Ryder D (1995) Independent role of beer proteins, melanoidins and polysaccharides in foam formation. J Am Soc Brew Chem 53:93-103. https://doi.org/10.1094/ ASBCJ-53-0093 
29. Kapp GR, Bamforth CW (2002) The foaming properties of proteins isolated from barley. J Sci Food Agric 82:1276-1281. https:// doi.org/10.1002/jsfa. 1177

30. Brahma A, Mandal C, Bhattacharyya D (2005) Characterization of a dimeric unfolding intermediate of bovine serum albumin under mildly acidic condition. Biochim Biophys Acta Proteins Proteom 1751:159-169. https://doi.org/10.1016/j.bbapap.2005.06.007

31. Holm NK, Jespersen SK, Thomassen LV et al (2007) Aggregation and fibrillation of bovine serum albumin. Biochim Biophys Acta Proteins Proteom 1774:1128-1138. https://doi.org/10.1016/j. bbapap.2007.06.008

32. Murayama K, Tomida M (2004) Heat-induced secondary structure and conformation change of bovine serum albumin investigated by Fourier transform infrared spectroscopy. Biochemistry 43:11526-11532. https://doi.org/10.1021/bi0489154

33. Praefcke GJK, Herrmann C (2005) Isotherme Titrationskalorimetrie (ITC) zur Charakterisierung biomolekularer Wechselwirkungen. BIOspektrum 1:44-47

34. Briggs DE, Boulton CA, Brookes PA et al (2004) Brewing Science and practice. Woodhead Publishing Limited and CRC Press LLC, Boca Raton
35. Malowicki MG, Shellhammer TH (2005) Isomerization and degradation kinetics of hop (Humulus lupulus) acids in a model wortboiling system. J Agric Food Chem 53:4434-4439. https://doi.org/ $10.1021 / \mathrm{jf0481296}$

36. Pöschl MR (2009) Die kolloidale Stabilität untergäriger Biere Einflussmöglichkeiten und Vorhersagbarkeit. Dissertation, Technische Universität München

37. Rajalingam D, Loftis C, Xu JJ et al (2009) Trichloroacetic acidinduced protein precipitation involves the reversible association of a stable partially structured intermediate. Protein Sci 18:980-993. https://doi.org/10.1002/pro.108

38. Koontz L (2014) Chapter one-TCA precipitation. Meth Enzymol 541:3-10. https://doi.org/10.1016/B978-0-12-420119-4.00001-X

39. Hanke S, Back W, Tauscher F (2008) Die Bittere ist entscheidend: Einflüsse auf die Hopfenausbeute und Trubbildung bei der Würzekochung. Brauindustrie: 34-37

Publisher's Note Springer Nature remains neutral with regard to jurisdictional claims in published maps and institutional affiliations. 